\title{
Influence of monocalcium phosphate on the properties of bioactive magnesium phosphate bone cement
}

Shaochun Lv ( $\sim$ acefire2008@163.com )

Jiamusi University

Tianyu Qu

Stevens Institute of Technology

Hisham Al-Ward

Tongji University

Liting Mu

Jiamusi University

Hongbin Qiu

Jiamusi University

Yunlong Zhang

Jiamusi University

Research article

Keywords: Magnesium phosphate, Bone cement, Monocalcium phosphate, Bioactivity

Posted Date: February 7th, 2022

DOI: https://doi.org/10.21203/rs.3.rs-1272878/v1

License: (c) (i) This work is licensed under a Creative Commons Attribution 4.0 International License.

Read Full License 


\section{Abstract}

Background: The bone defects caused by different reasons led to deformity and dysfunction of human body. Considering the need for clinical application, it was essential for bone regeneration to exploit a scaffold with bioactive bone cement. In this paper, we fabricated bioactive magnesium phosphate bone cement (BMPC) at room temperature, then it was set at $37^{\circ} \mathrm{C}$ and $100 \%$ humidity for $2 \mathrm{~h}$.

Methods: The process was as follows. $\mathrm{MgO}$ was formed by calcining $\mathrm{Mg}_{2}(\mathrm{OH})_{2} \mathrm{CO}_{3}, \mathrm{MgO}, \mathrm{KH}_{2} \mathrm{PO}_{4}$ and carboxymethyl chitosan were mixed to form magnesium phosphate bone cement(MPC), then $\mathrm{Ca}\left(\mathrm{H}_{2} \mathrm{PO}_{4}\right)_{2}$ was added to neutralize alkaline product after MPC hydration to fabricate bioactive magnesium phosphate bone cement (BMPC). The influence of doped content of $\mathrm{Ca}\left(\mathrm{H}_{2} \mathrm{PO}_{4}\right)_{2}$ on the properties of bone cement was discussed.

Results: The results showed that $\mathrm{Ca}\left(\mathrm{H}_{2} \mathrm{PO}_{4}\right)_{2}$ and carboxymethyl chitosan can adjust the setting time of bone cement within the scope of 8 minute and 25 minute. The compressive strength increased first and then decreased. After $48 \mathrm{~h}$ without additional pressure, the compressive strength reached the maximum value, so it was about of $38.6 \mathrm{MPa}$. $\mathrm{Ca}\left(\mathrm{H}_{2} \mathrm{PO}_{4}\right)_{2}$ and carboxymethyl chitosan can play a synergistic role in regulating the BMPC properties. BMPC was degradable in the simulated body fluid (SBF). The results of cytotoxicity experiment and laser confocal microscopy experiment indicated that BMPC fabricated at room temperature had better biocompatibility and degradability, which was more consistent with clinical operation requirement.

Conclusions: BMPC can be used as a promising orthopedic material, and it can meet with the needs for repairing bone defects.

\section{Introduction}

The treatment of bone tissue defect was a common problem in clinics. At present, the traditional autologous bone transplantation was still the "golden standard" for the clinical treatment of bone defects. However, autologous bone transplantation could increase patients' additional trauma. It was lack of bone source and was limited by donors. Besides, it could also increase the number of operations and prolong the healing period. Its future development prospect was not ideal ${ }^{[1,2]}$. Compared with traditional bone transplantation, degradable bioactive bone cement was prepared to repair bone defects had the advantages of minor damage by bone tissue engineering technology. It was necessary for proper repair of bone morphology in the defect area and no obvious antigenicity ${ }^{[3,4]}$. Monocalcium phosphate $\left(\mathrm{Ca}\left(\mathrm{H}_{2} \mathrm{PO}_{4}\right)_{2}\right)$, also known as acidic calcium phosphate, was a colorless, granular, or crystalline powder. It existed in the form of $\mathrm{Ca}\left(\mathrm{H}_{2} \mathrm{PO}_{4}\right)_{2} \cdot \mathrm{H}_{2} \mathrm{O}$ at room temperature. The aqueous solution was acidic and lost crystalline water after heating. It was widely used as buffer and food additive $\mathrm{e}^{[5,6]}$. Chitosan was the product of deacetylation of chitin. It was the most important derivative of chitin. The surface of chitosan was hydrophilic. As an essential water-soluble chitosan derivative, carboxymethyl chitosan had good biocompatibility and biodegradability. It was widely used in hydrogels, wound healing biomaterials, and 
tissue engineering scaffold materials ${ }^{[7]}$. Previous studies showed that carboxymethyl chitosan had no antigenicity in animals and was used as an additive for bone defect repair materials and as a fabrication of bone cement ${ }^{[8,9]}$. Magnesium phosphate cement (MPC) was an inorganic non-metallic bioceramic material generated by slightly soluble salinization reaction. It was usually used in the industrial field. Based on the characteristics of high early strength and rapid curing, it had good biocompatibility and biodegradability. In the recent years, it had attracted the attention of bioactive bone scaffold researchers ${ }^{[10,11]}$. MPC was fabricated by mixing magnesium oxide $(\mathrm{MgO})$ and ammonium dihydrogen phosphate $\left(\mathrm{NH}_{4} \mathrm{H}_{2} \mathrm{PO}_{4}\right)$ as solid components. The main reaction product was magnesium ammonium phosphate $\left(\mathrm{MgNH}_{4} \mathrm{PO}_{4}\right)$, commonly known as guano stone, a natural crystal ${ }^{[12,13]}$. Accordingly, this process led to the release of $\mathrm{NH}_{3}$ during the degradation of bone cement, which was easy to contaminate environment and was toxic to the implanted tissue. ${ }^{[14]}$ Potassium dihydrogen phosphate $\left(\mathrm{KH}_{2} \mathrm{PO}_{4}\right)$ was applied to replace $\mathrm{NH}_{4} \mathrm{H}_{2} \mathrm{PO}_{4}$ in the fabrication of industrial cement ${ }^{[15,16]}$. Compared with $\mathrm{NH}_{4} \mathrm{H}_{2} \mathrm{PO}_{4}$, $\mathrm{KH}_{2} \mathrm{PO}_{4}$ had a smaller dissociation constant and lower solubility, which was easier to control the reaction rate. Also, it did not produce $\mathrm{NH}_{3}$ when reacting with water. The final product was magnesium potassium phosphate $\left(\mathrm{MgKPO}_{4}\right)$, which was isomorphic with guanite ${ }^{[17,18]}$. However, in the research field of bioactive bone cement, there were few reports on the determination of $\mathrm{pH}$ of $\mathrm{MgKPO}_{4}$ in the aqueous phase and the effect of $\mathrm{Ca}\left(\mathrm{H}_{2} \mathrm{PO}_{4}\right)_{2}$ on the properties of MPC bone cement.

As for the temperature conditions for the fabrication of bone cement, there were several reports on the fabrication of bone cement below $0^{\circ} \mathrm{C}[19,20]$. It was reported that the mechanical properties of bone cement fabricated at low temperature in industry were not optimistic ${ }^{[21]}$. In clinical practice, the temperature in the operating room was generally controlled at $20 \sim 26^{\circ} \mathrm{C}^{[22,23]}$. It was necessary that solid and liquid phases of bone cement was mixed and stirred in proportion at room temperature and implanted into the bone defect quickly. Therefore, it was significative to carry out more researches on the fabrication of bone cement at room temperature.

In this essay, bioactive magnesium phosphate bone cement was investigated. Firstly, $\mathrm{MgO}, \mathrm{KH}_{2} \mathrm{PO}_{4}$ and carboxymethyl chitosan were mixed at $25^{\circ} \mathrm{C}$ to fabricate bioactive magnesium phosphate bone cement (BMPC), and $\mathrm{pH}$ of MPC hydration product $\mathrm{MgKPO}_{4}$ was measured. Then $\mathrm{Ca}\left(\mathrm{H}_{2} \mathrm{PO}_{4}\right)_{2}$ was added to MPC. The acidity produced by the degradation of $\mathrm{Ca}\left(\mathrm{H}_{2} \mathrm{PO}_{4}\right)_{2}$ was utilized to neutralize the alkalinity of $\mathrm{MgKPO}_{4}$, the main hydration product of MPC. Finally, the effects of $\mathrm{Ca}\left(\mathrm{H}_{2} \mathrm{PO}_{4}\right)_{2}$ and carboxymethyl chitosan on $\mathrm{pH}$, preserving time, compressive strength, degradability, cell morphology, and biocompatibility of bone cement were discussed.

\section{Materials And Methods}

\subsection{Fabrication of BMPC samples}


BMPC was composed of solid powder and liquid phase (deionized water). The solid powder was made from $\mathrm{MgO}, \mathrm{KH}_{2} \mathrm{PO}_{4}$, carboxymethyl chitosan and $\mathrm{Ca}\left(\mathrm{H}_{2} \mathrm{PO}_{4}\right)_{2}$. Among them, $\mathrm{MgO}$ was prepared by heating and decomposition of $\mathrm{Mg}_{2}(\mathrm{OH})_{2} \mathrm{CO}_{3}$. All powder materials were obtained from Sinopharm Chemical Reagent Co., China. $\mathrm{Mg}_{2}(\mathrm{OH})_{2} \mathrm{CO}_{3}$ was calcined in muffle furnace to $1500{ }^{\circ} \mathrm{C}$, the heating rate was $10{ }^{\circ} \mathrm{C} / \mathrm{min}$, kept warm for $2 \mathrm{~h}$, cooled with the furnace, wet ball milled with alcohol for $2 \mathrm{~h}$, and sieved through 300 mesh nylon sieve to prepare $\mathrm{MgO} . \mathrm{KH}_{2} \mathrm{PO}_{4}$ and $\mathrm{Ca}\left(\mathrm{H}_{2} \mathrm{PO}_{4}\right)_{2}$ were respectively screened through a 300 mesh nylon screen after ball milling. Then carboxymethyl chitosan powder was added by $1.5 \%$ of mass fraction ${ }^{[24]}$. At $25^{\circ} \mathrm{C}$, deionized water was added at a solid-liquid ratio of $1.6 \mathrm{~g} / \mathrm{ml}$, after being thoroughly mixed, made into bioactive cement paste, and placed in a 3D printing polyethylene mold (size $10 \times 10 \times 5 \mathrm{~mm}$ ) without additional pressure. The BMPC sample was collected after restoring at $37^{\circ} \mathrm{C}$ and $100 \%$ relative humidity for $48 \mathrm{~h}$. The composition of BMPC samples was analyzed by X-ray crystal diffraction (XRD, D8-Advance, Germany). The surface morphology and microstructure of BMPC were observed and studied by scanning electron microscope (SEM, JSM-7800, Japan).

\section{$2.2 \mathrm{pH}$ determination of MPC hydration product}

Four different mass ratios of $\mathrm{MgO}$ and $\mathrm{KH}_{2} \mathrm{PO}_{4}$, i.e., 1:2, 1:3, 1:4 and 1:5, were selected. carboxymethyl chitosan was added by a $1.5 \%$ mass fraction and synthesized MPC with the participation of deionized water. The main hydration product $\mathrm{MgKPO}_{4}$ was analyzed by XRD. The MPC sample was immersed in normal saline with a solid-liquid ratio of $0.2 \mathrm{~g} / \mathrm{ml}$ and placed in a constant temperature oscillator for $24 \mathrm{~h}$. The supernatant was taken, and the $\mathrm{pH}$ was measured. $\mathrm{Ca}\left(\mathrm{H}_{2} \mathrm{PO}_{4}\right)_{2}$ was introduced at the mass ratio of 1:2 $\left(\mathrm{MgO}\right.$ and $\left.\mathrm{KH}_{2} \mathrm{PO}_{4}\right)$ in order to prepare different mass fractions of $\mathrm{Ca}\left(\mathrm{H}_{2} \mathrm{PO}_{4}\right)_{2}$ bone cement samples (0wt.\%, 20wt.\%, 40wt.\%, 60wt.\%), which were recorded as BMPC0, BMPC20, BMPC40 and BMPC60 respectively. The effects of different content of $\mathrm{Ca}\left(\mathrm{H}_{2} \mathrm{PO}_{4}\right)_{2}$ on the properties of $\mathrm{BMPC}$ were examined.

\subsection{Characterization of BMPC samples}

In order to determine the $\mathrm{pH}$ of BMPC soaking solution with different content of $\mathrm{Ca}\left(\mathrm{H}_{2} \mathrm{PO}_{4}\right)_{2}, \mathrm{BMPC}$ samples were immersed in normal saline at a solid-liquid ratio of $0.2 \mathrm{~g} / \mathrm{mL}$ and stored in a constant temperature oscillator for $24 \mathrm{~h}$. The supernatant was taken and $\mathrm{pH}$ was determined by a $\mathrm{pH}$ meter. The setting time of BMPC was measured using a Vicat meter. The Vicat meter which was used, had a sliding metal round rod with a weight of $300 \mathrm{~g}$ and a test needle of $1 \mathrm{~mm}$ diameter and $50 \mathrm{~mm}$ length at the lower end of the rod. The setting time was the time required from mixing the solid and liquid phases of the composite bone cement to the time when the test needle failed to penetrate more than $1 \mathrm{~mm}$ into the specimen. The test was repeated three times, and the average value was calculated. After $48 \mathrm{~h}$ setting of the bone cement, the compressive strength was measured with a loading rate of $2 \mathrm{~mm} / \mathrm{min}$ using the MTS810 universal mechanical testing machine, and five samples were taken at each group. The degradation of different BMPC in SBF was determined by the degradation rate at different time points. BMPC samples $(10 \mathrm{~mm} \times 10 \mathrm{~mm} \times 5 \mathrm{~mm})$ were dried for $2 \mathrm{~h}$ as initial weight $\left(\mathrm{W}_{0}\right)$. Then, BMPC samples were immersed in $\mathrm{SBF}$ at $37^{\circ} \mathrm{C}$ in a thermostatic shaker with a solid-to-liquid mass ratio of $1: 20 \mathrm{~g} / \mathrm{ml}$. The 
solution was renewed every two days. The weights of BMPC were determined at days 3, 5, 7, 14, 21 and 28 , respectively. The operation was performed by removing the specimen from the liquid after immersion, rinsing it with deionized water, drying it for $2 \mathrm{~h}$, and recording the new weight of all specimen. All values were the average of three tests. The degradation rate was calculated by the following formula (1):

Degradation rate $=\left(\mathrm{W}_{0}-\mathrm{W}_{\mathrm{t}}\right) / \mathrm{W}_{0} \times 100 \%(1)$

\subsection{Cell culture and cytotoxicity experiment}

Mouse osteoblasts 3T3E1 were selected and cultured in complete Roswell Park Memorial Institute 1640 (RPMI) containing $10 \%$ foetal bovine serum (FBS), $1 \%$ antibiotics (penicillin, streptomycin) and at $37^{\circ} \mathrm{C}$ in a humidified incubator with $5 \% \mathrm{CO}_{2}$. Cells were harvested after the confluence with $0.25 \%$ trypsin and inoculated individually on culture dishes at an initial density of 2000 cells per well, placed in 96 well culture dishes, and incubated at $37^{\circ} \mathrm{C} / \mathrm{CO}_{2}$. The culture medium was changed every 3 days. BMPC extracts with different mass fractions of $\mathrm{Ca}\left(\mathrm{H}_{2} \mathrm{PO}_{4}\right)_{2}$ were used as the experimental group, and a normal cell culture medium was used as the control group. The BMPC extracts were prepared according to the method in the literature ${ }^{[25]}$. First, the bone cement raw material was added to serum-free RPMI at a solidliquid ratio of $0.2 \mathrm{~g} / \mathrm{ml}$ under aseptic conditions to obtain the solution, which was incubated at $37^{\circ} \mathrm{C}$ for $24 \mathrm{~h}$ and then centrifuged, and the supernatant was collected, refrigerated at $4^{\circ} \mathrm{C}$ and stored for further use. The cells were cultured for 1 day, 3 days and 5 days, respectively. The cytotoxicity of BMPC was estimated by MTT (3-(4,5-dimethylthiazole-2-yl)-2,5-diphenyl-2H-tetrazolium bromide) assay. To each well, $20 \mu \mathrm{l}$ of MTT solution was added, and incubation was continued at $37{ }^{\circ} \mathrm{C}$ and $5 \% \mathrm{CO}_{2}$ for $4 \mathrm{~h}$. The supernatant in the wells was then discarded, and $200 \mu \mathrm{L}$ of dimethyl sulfoxide (DMSO) was added to fully dissolve the purple crystals. On days 1, 3, and 5, respectively, the absorbance value of each well at 490 $\mathrm{nm}$ was measured by an enzyme maker OD. The relative growth rate (RGR) was calculated according to the measured OD value by the following formula (2), and the test results were evaluated according to the cytotoxicity grade standard (Table 1$)^{[26]}$.

$R G R(\%)=A_{\text {Test }} / A_{\text {control }} \times 100 \%(2)$

\subsection{Laser confocal microscopy experiment}

Mouse osteoblasts $3 \mathrm{~T} 3 \mathrm{E} 1$ in logarithmic growth stage were taken at $37{ }^{\circ} \mathrm{C}, 5 \% \mathrm{CO}_{2}$ in a constant temperature oven, and treated with $4 \times 10^{5} / \mathrm{ml}$ in four groups BMPC extracts with different levels of $\mathrm{Ca}\left(\mathrm{H}_{2} \mathrm{PO}_{4}\right)_{2}$, respectively. After 5 days of culture, the cells were fixed with $0.2 \mathrm{ml}$ of $4 \%$ paraformaldehyde, and the wells were placed in the thermostat for $10 \mathrm{~min}$. The fixative solution was pipetted out, rinsed with PBS, and $0.5 \%$ Triton $x-10005 \mathrm{ml}$ was added, and the membrane was permeabilized in the thermostat for $20 \mathrm{~min}$, after which the permeabilized solution was pipetted out, rinsed with PBS, and $0.5 \mathrm{ml}$ of staining solution was added to re-stain the plates for $5 \mathrm{~min}$, and the re-staining solution was pipetted out and rinsed with PBS. $200 \mu \mathrm{L}$ of rhodamine ghostpen ring peptide was added and treated in a dark room at 
room temperature for $40 \mathrm{~min}$ and then sealed with fluorescence quencher after PBS rinsing. After material treatment, cell morphology and growth were observed using laser confocal microscopy.

\section{Results And Discussion}

\subsection{Hydration products and $\mathrm{pH}$ of MPC}

Fig.1 showed XRD and $\mathrm{pH}$ results of $\mathrm{MgO}$ and $\mathrm{KH}_{2} \mathrm{PO}_{4}(\mathrm{MPC})$ at different mass ratios. According to the analysis from the XRD data, all hydration products of MPC specimens were composed of $\mathrm{MgO}$ and $\mathrm{KMgPO}_{4}$ (Figure 1), and the main diffraction peaks were $\mathrm{KMgPO}_{4}$. However, it wasn't revealed the peak of carboxym ethyl chitosan. The diffraction peaks $\mathrm{MgO}$ were weak and it indicated that there was only a small amount of $\mathrm{MgO}$. The diffraction peak intensity of $\mathrm{MgO}$ decreased with the increase of $\mathrm{KH}_{2} \mathrm{PO}_{4}$, as the diffraction peak intensity of $\mathrm{KMgPO}_{4}$ enhanced with the increase of $\mathrm{KH}_{2} \mathrm{PO}_{4}$. Therefore, it indicated that $\mathrm{MgO}$ was almost completely transformed into $\mathrm{KMgPO}_{4}$. With the increase of $\mathrm{KMgPO}_{4}$, the $\mathrm{pH}$ of MPC soaking solution enhanced, indicating that $\mathrm{KMgPO}_{4}$ (hydration product of MPC) was alkaline.

\subsection{The SEM images of BMPC specimens}

Figure 2 showed surface morphology of BMPC specimens with different content of $\mathrm{Ca}\left(\mathrm{H}_{2} \mathrm{PO}_{4}\right)_{2}$ after setting for 48 hours. It was found that BMPCO contained prismatic crystals. It was speculated that these crystals were $\mathrm{KMgPO}_{4}$ as well as clay materials with dense morphology and structure, as shown in Figure $2(\mathrm{a}, \mathrm{b})$. With the increase of $\mathrm{Ca}\left(\mathrm{H}_{2} \mathrm{PO}_{4}\right)_{2}$ content, prismatic crystals disappeared and clay materials increased, which was consistent with the XRD results. $\mathrm{KMgPO}_{4}$ disappeared with the increase of $\mathrm{Ca}\left(\mathrm{H}_{2} \mathrm{PO}_{4}\right)_{2}$. It could be seen that clay materials accumulated together, resulting in high strength of the specimens, as shown in Figure 2(c,d) to Figure 2(e, f). Moreover, there were many pores in the clay materials, which were consistent with the experimental results observed by Wang s, et al(2019) ${ }^{[27]}$. The existence of these pores was not only conducive to the degradation of bone cement and phosphate deposition, but also conducive to the adhesion and proliferation of osteoblasts, so it induced the growth of new bone. Therefore, it could result in the degradation of BMPC specimens (Figure $2(\mathrm{~g}, \mathrm{~h})$ ).

\subsection{The results of characterization of BMPC samples}

The $\mathrm{pH}$ of BMPC extracts were shown in Fig. 3. The pH decreased with the increase of $\mathrm{Ca}\left(\mathrm{H}_{2} \mathrm{PO}_{4}\right)_{2}$ content, which was related to the hydration product after $48 \mathrm{~h}$. With the increase of $\mathrm{Ca}\left(\mathrm{H}_{2} \mathrm{PO}_{4}\right)_{2}$ content, $\mathrm{KMgPO}_{4}$ phase and $\mathrm{MgO}$ phase disappeared, as $\mathrm{MgHPO}_{4}$ phase appeared, so it resulted in the decrease of $\mathrm{pH}$ of $\mathrm{BMPC}$ extracts. It showed that $\mathrm{KMgPO}_{4}$ was alkaline during immersion. Moreover, the research results showed that the $\mathrm{pH}$ of BMPC extracts with $40 \%$ or more $\mathrm{Ca}\left(\mathrm{H}_{2} \mathrm{PO}_{4}\right)_{2}$ decreased to less than 7.40 , which was close to the $\mathrm{pH}$ value of simulated body fluid (SBF) used in general cell experiments. This condition of $\mathrm{pH}$ environment promoted cell growth and proliferation. 
The effect of different amounts of $\mathrm{Ca}\left(\mathrm{H}_{2} \mathrm{PO}_{4}\right)_{2}$ on the setting time was shown in Fig. 4. With increasing $\mathrm{Ca}\left(\mathrm{H}_{2} \mathrm{PO}_{4}\right)_{2}$ content, the setting time of $\mathrm{BMPC}$ was increased from $8 \mathrm{~min}$ to $25 \mathrm{~min}$, a time range that was consistent with the operating time needed for general clinical bone defect repair. When the ratio of $\mathrm{MgO}$ to $\mathrm{KH}_{2} \mathrm{PO}_{4}$ was $1: 2$, the content of $\mathrm{MgO}$ was relatively overreacted (Table. 2). In contrast, as the $\mathrm{Ca}\left(\mathrm{H}_{2} \mathrm{PO}_{4}\right)_{2}$ content increased, the acidity of the reaction system increased, more crystalline products were generated, and the main product $\mathrm{KMgPO}_{4}$ disappeared, prolonging the time for the reaction to reach equilibrium and resulting in a longer setting time of bone cement, which facilitated implantation of bone cement.

Figure 5 showed the effect of $\mathrm{Ca}\left(\mathrm{H}_{2} \mathrm{PO}_{4}\right)_{2}$ content on compressive strength of BMPC specimens. After BMPC slurry prepared at $25^{\circ} \mathrm{C}$ and static set for $48 \mathrm{~h}$, the compressive strength increased the beginning, then it decreased with the increase of $\mathrm{Ca}\left(\mathrm{H}_{2} \mathrm{PO}_{4}\right)_{2}$ content without additional pressure. The compressive strength of BMPC40 reached the maximum value of $38.6 \mathrm{MPa}$, which was $31.4 \mathrm{MPa}$ higher than that of magnesium ammonium phosphate bone cement prepared at low temperature ${ }^{[20]}$. The increase of compressive strength was due to the decrease of $\mathrm{pH}$ in the reaction system, then it resulted in more hydration products similar to clay particles (Fig. 2). These granular materials were closely staggered and stacked together to form high compressive strength. Therefore, the specimens not only performed satisfactory mechanical strength, but also met the needs of on-site fabrication of bone cement at room temperature. Compared with BMPC40, the compressive strength of BMPC60 decreased. It was the reason that crystal structure became irregular as the crystallinity of hydration products decreased (Fig. 2), which cannot form a high compressive strength and resulted in a decrease of compressive strength with BMPC60.

After bone cement was set for $48 \mathrm{~h}, \mathrm{KMgPO}_{4}$ and surplus unreacted $\mathrm{MgO}$ was examined from the reaction system of $\mathrm{BMPCO}$. With the increase of $\mathrm{Ca}\left(\mathrm{H}_{2} \mathrm{PO}_{4}\right)_{2}$ content, $\mathrm{MgO}$ gradually disappeared, and $\mathrm{MgHPO}_{4}$, $\mathrm{Mg}_{3}\left(\mathrm{PO}_{4}\right)_{2}, \mathrm{Ca}_{3}\left(\mathrm{PO}_{4}\right)_{2}$ and $\mathrm{Ca}_{10}\left(\mathrm{PO}_{4}\right)_{6}(\mathrm{OH})_{2}$ appeared. $\mathrm{KMgPO}_{4}$ disappeared in the reaction system with more than $40 \% \mathrm{Ca}\left(\mathrm{H}_{2} \mathrm{PO}_{4}\right)_{2}$. Finally, $\mathrm{Mg}_{3}\left(\mathrm{PO}_{4}\right)_{2}, \mathrm{MgHPO}_{4}, \mathrm{Ca}_{10}\left(\mathrm{PO}_{4}\right)_{6}(\mathrm{OH})_{2}$ and $\mathrm{MgKH}\left(\mathrm{PO}_{4}\right)_{2}$ were formed. $\mathrm{Ca}_{10}\left(\mathrm{PO}_{4}\right)_{6}(\mathrm{OH})_{2}$ was also known as hydroxyapatite (HAP), an inorganic component of human bone.

After degrading for 28 days, $\mathrm{Mg}_{3}\left(\mathrm{PO}_{4}\right)_{2}$ could be examined from all specimens. Among them, the degradation products of BMPC with $\mathrm{Ca}\left(\mathrm{H}_{2} \mathrm{PO}_{4}\right)_{2}$ included $\mathrm{Mg}_{3}\left(\mathrm{PO}_{4}\right)_{2}, \mathrm{MgHPO}_{4}$, pyrophosphate and HAP. It should be pointed out that $\mathrm{BMPC}$ filled with $\mathrm{Ca}\left(\mathrm{H}_{2} \mathrm{PO}_{4}\right)_{2}$ produced $\mathrm{MgHPO}_{4}$ after setting for $48 \mathrm{~h}$. After degradation for 28 days, $\mathrm{MgHPO}_{4}$ still existed, while other products were transformed into magnesium phosphate, pyrophosphate and HAP (Table 2). Thus, $\mathrm{MgHPO}_{4}$ could be regarded as buffering agent in the reaction system, and the regulation of $\mathrm{pH}$ with $\mathrm{BMPC}$ depended on the existence of $\mathrm{MgHPO}_{4}$.

Figure 6 showed the degradation rate of BMPC samples soaked in simulated body fluid (SBF) at different time. Obviously, BMPC degraded in SBF as time went on and the degradation rate was related to the amount of products (Table 2). It can be found that after degrading for 28 days, the product amount of 
BMPC40 samples had the most significant reduction and the highest degradation rate. The results showed that the more products disappeared, the faster the degradation was.

\subsection{The results of cytotoxicity with BMPC by MTT assay}

MTT assay was widely applied to detect the bioactivity or cytotoxicity of biomaterials. MTT assay was selected to detect the extracts of BMPC samples to determine the cytotoxicity to mouse osteoblasts 3T3E1. According to RGR and toxicity grade standard (Table 3), when $\mathrm{Ca}\left(\mathrm{H}_{2} \mathrm{PO}_{4}\right)_{2}$ content was less than $40 \%$, the toxicity grade of BMPC samples was grade 1 . When $\mathrm{Ca}\left(\mathrm{H}_{2} \mathrm{PO}_{4}\right)_{2}$ content reached $40 \%$ or more, the toxicity grade of BMPC samples was grade 0 (Fig. 7, Table 3). It indicated that BMPC40 and BMPC60 samples had good biocompatibility, which were consistent with the $\mathrm{pH}$ results of BMPC extracts (Fig. 3). It was the reason that addition of $\mathrm{Ca}\left(\mathrm{H}_{2} \mathrm{PO}_{4}\right)_{2}$ reduced the $\mathrm{pH}$ of BMPC extracts, which was close to the $\mathrm{pH}$ of simulated body fluid, thereby it was benefit to improve the biocompatibility of bone cement. It also proved that the alkaline environment of $\mathrm{KMgPO}_{4}$ was not suitable for the growth, adhesion and proliferation of mouse osteoblasts 3T3E1.

\subsection{The results of laser confocal microscopy experiment}

The results of laser confocal microscopy experiment were shown in Fig. 8. The morphology of mouse osteoblasts 3T3E1 in bone cement extracts was irregular, mostly triangular and polygonal, with many protrusions, mononuclear and oval nucleus. The cell matrix was wrapped around the nucleus, and the pseudopodia between cells fused with each other. It indicated that the cells grew on the matrix of all bone cement samples. In terms of different $\mathrm{Ca}\left(\mathrm{H}_{2} \mathrm{PO}_{4}\right)_{2}$ contents, compared with BMPCO (Fig. 8(a)) and BMPC20 (Fig. 8(b)), the number of osteoblasts with BMPC40 and BMPC60 increased significantly (Fig. $8(\mathrm{c}, \mathrm{d}))$. It suggested that with the increase of $\mathrm{Ca}\left(\mathrm{H}_{2} \mathrm{PO}_{4}\right)_{2}$ content, the changes of bone cement degradation products and alkaline environment promoted cell proliferation and differentiation. This was consistent with the cytotoxicity results of BMPC by MTT assay. Compared with the other groups, the largest number of cells was detected in BMPC60 extracts (Fig. 8 (c, d)), which could be interpreted for two reasons. On the one hand, the $\mathrm{pH}$ of BMPC40 and BMPC60 were close to the $\mathrm{pH}$ of simulated body fluid (Fig. 3), which was suitable for cell growth and proliferation. On the other hand, the contents of calcium ions, magnesium ions and phosphate in the solution were high, which provided a suitable environment for the growth of osteoblasts.

\section{Discussion}

Here we developed novel bioactive magnesium phosphate bone cement (BMPC) with improved physicochemical properties by incorporating different ratios of $\mathrm{Ca}\left(\mathrm{H}_{2} \mathrm{PO}_{4}\right)_{2}$ into magnesium phosphate bone cement (MPC). It was revealed by $\mathrm{X}$-ray diffraction (XRD) that the mass ratio of magnesium oxide (MgO) to potassium dihydrogen phosphate $\left(\mathrm{KH}_{2} \mathrm{PO}_{4}\right)$ was 1:2. The major hydration reaction of MPC made from $\mathrm{MgO}$ and $\mathrm{KH}_{2} \mathrm{PO}_{4}$ was: 
$\mathrm{K}^{+}+\mathrm{Mg}^{2+}+\mathrm{PO}_{4}^{3-}=\mathrm{MgKPO}_{4}$

Besides the $\mathrm{MgKPO}_{4}$ and unreacted $\mathrm{MgO}, \mathrm{XRD}$ analysis did not reveal any other hydration products. It indicated that carboxymethyl chitosan mainly performed as micro-filler in the MPC reaction system, therefore, it does not involve in the formation process of hydration products. After adding different concentrations of $\mathrm{Ca}\left(\mathrm{H}_{2} \mathrm{PO}_{4}\right)_{2}$, the typical peaks of $\mathrm{MgO}$ and $\mathrm{KMgPO}_{4}$ gradually disappeared in XRD analysis, indicating that all samples were transformed into other hydration products.

The setting time was one of the vital properties which could reflect the polymerization time for repairing bone defects ${ }^{[28]}$. The setting time of MPC was greatly affected by the conditions of powder size, surface area, $\mathrm{MgO}$ content, powder-to-liquid ratio, etc. ${ }^{[29]}$. In the preparation process of inorganic salt bone cement, the acid-base reaction rate was fast and difficult to control, so that the setting time was very short ${ }^{[30]}$. Several former studies had revealed that a setting time of 8 to 20 minutes was suitable for implanting bone cement in surgery ${ }^{[30]}$. This study showed that the setting time could be prolonged from 8 min to 25 min by adjusting the content of $\mathrm{Ca}\left(\mathrm{H}_{2} \mathrm{PO}_{4}\right)_{2}$ in MPC, with the carboxymethyl chitosan at a fixed ratio. Therefore, it was sufficient long for repairing the bone defects by injecting and shaping the cement. The setting time prolonged because $\mathrm{Ca}\left(\mathrm{H}_{2} \mathrm{PO}_{4}\right)_{2}$ as an acid salt, it played a certain buffering role in the reaction system, which can decelerate the rate of hydration reaction. Moreover, the carboxymethyl chitosan can forms coatings to cover the surface of $\mathrm{MgO}$ and $\mathrm{KH}_{2} \mathrm{PO}_{4}$ to reduce its hydration, slowing down the hydration reaction. We speculate that $\mathrm{Ca}\left(\mathrm{H}_{2} \mathrm{PO}_{4}\right)_{2}$ can coordinated with the carboxymethyl chitosan in this process. Without a buffer, the hydration reaction can take a violent exothermic effect ${ }^{[31]}$. The prolonged setting time indicated the composite cement had a moderate hydration reaction, generating less heat during the setting process. It can be helpful to avoid tissue damage and apoptosis $^{[32]}$.

Bone cement needs to achieve a certain mechanical strength in clinical applications, at least to meet the compressive strength of the cancellous bon $\mathrm{e}^{[33]}$. We found that the compressive strength first increased and later decreased with the $\mathrm{Ca}\left(\mathrm{H}_{2} \mathrm{PO}_{4}\right)_{2}$ concentration increasing. The maximum value of compressive strength was $38.6 \mathrm{MPa}$, with BMPC40. The increase of compressive strength was due to the decrease of $\mathrm{pH}$ value in the reaction system, resulting in more hydration products similar to clay particles. These granular materials were closely staggered and stacked together to form high compressive strength. Therefore, the specimen not only had good mechanical strength, but also met the needs of on-site preparation of bone cement at room temperature. Compared with BMPC40, the compressive strength of BMPC60 decreased. This was because the crystallinity of the hydration product of BMPC60 reduced, the crystal structure became irregular, and the high compressive strength cannot be formed, resulting in the decrease of compressive strength. In addition, carboxymethyl chitosan, as a hydrophilic polymer, it may adsorb deionized water in the liquid phase and forms a high viscosity coating on the cement surface. This can be observed from SEM images. MPC showed many brittle crystal cracks, while carboxymethyl chitosan filled these cracks, forming a dense microstructure, which had a certain degree of fracture resistance. 
$\mathrm{pH}$ should also be considered because it can significantly affect osteogenesis of bone cement ${ }^{[34]}$.

Generally, surplus MgO in MPC composites can lead to a large amount of $\mathrm{OH}^{-}$. In order to decrease the alkalinity of hydration products, a relatively low $\mathrm{Mg} / \mathrm{P}$ ratio of 1:2 was adopted. We also utilized the acidic characteristic of $\mathrm{Ca}\left(\mathrm{H}_{2} \mathrm{PO}_{4}\right)_{2}$ in aqueous solution to decrease the $\mathrm{pH}$. With the increase of $\mathrm{Ca}\left(\mathrm{H}_{2} \mathrm{PO}_{4}\right)_{2}$ content, $\mathrm{KMgPO}_{4}$ phase and $\mathrm{MgO}$ phase disappeared, as $\mathrm{MgHPO}_{4}$ phase appeared, the $\mathrm{pH}$ of $\mathrm{BMPC}$ extracts decreased. Moreover, the results showed that the $\mathrm{pH}$ of BMPC extracts with $40 \%$ or more $\mathrm{Ca}\left(\mathrm{H}_{2} \mathrm{PO}_{4}\right)_{2}$ decreased to less than 7.40 , which was close to the $\mathrm{pH}$ value of simulated body fluid (SBF) used in general cell experiments. In addition, carboxymethyl chitosan was an amphoteric ether derivative with active groups, such as hydroxyl(-OH), carboxyl (- $\mathrm{COOH})$, and amino(- $\left.-\mathrm{NH}_{2}\right)$, it can also decrease the $\mathrm{pH}$ of BMPC. We speculated that $\mathrm{Ca}\left(\mathrm{H}_{2} \mathrm{PO}_{4}\right)_{2}$ and carboxymethyl chitosan can play a synergistic role in $\mathrm{pH}$ regulation.

The degradation rate or biodegradability was another important property of bone cement. There was evidence that lower degradation rate can be caused by lower porosity ${ }^{[35]}$. We found that the degradation rate was faster after adding $\mathrm{Ca}\left(\mathrm{H}_{2} \mathrm{PO}_{4}\right)_{2}$ to MPC cement at first one week. Then, the degradation rate of $\mathrm{Ca}\left(\mathrm{H}_{2} \mathrm{PO}_{4}\right)_{2}$ groups gradually slow down, although the increasing trend still existed. We speculated that the $\mathrm{Ca}\left(\mathrm{H}_{2} \mathrm{PO}_{4}\right)_{2}$, as a buffer, took action in the degradation process. Therefore, this reaction process can be controlled at a comparatively moderate condition. The carboxymethyl chitosan may be also play a synergistic role, however, it still needed to be testified by further study. We have noticed that when the $\mathrm{Ca}\left(\mathrm{H}_{2} \mathrm{PO}_{4}\right)_{2}$ concent was $60 \%$, the degradation rate decreased slightly compared to BMPC40. The differences in degradation and pH of BMPC60 may be caused by the direct dissolution of $\mathrm{Ca}\left(\mathrm{H}_{2} \mathrm{PO}_{4}\right)_{2}$ after binding saturation. Studies have shown that magnesium ions $\left(\mathrm{Mg}^{2+}\right)$ have properties similar to those of bone tissue and displays antibacterial activity, excellent biocompatibility, and biodegradability ${ }^{[36]}$. Water can penetrate the BMPC scaffold, allowing $\mathrm{Mg}^{2+}$ to diffuse from the scaffold. The release of $\mathrm{Mg}^{2+}$ was generally positively correlated with the degradation of BMPC, and the precipitation trend of $\mathrm{Mg}^{2+}$ achieved a stable state. Therefore, In this work, under the condition of controllable degradation rate, $\mathrm{Mg}^{2+}$ may coordinated with $\mathrm{Ca}^{2+}$, acting as the nuclei for forming hydroxyapatite to achieve bone matrix mineralization.

In this study, in vitro cytotoxicity experiment and laser confocal microscopy experiment were used to evaluate the cellular response to biomaterials, detecting the cell morphology and internal structure. The results of in vitro cell culture showed that BMPC composites had no cytotoxicity. After 5 days of culture, 3T3E1 cells proliferated and adhered to BMPC composites better than MPC(BMPC0). In addition, compared with MPC, the cell viability on BMPC increased with the $\mathrm{Ca}\left(\mathrm{H}_{2} \mathrm{PO}_{4}\right)_{2}$ content adding. The osteogenic response to bone cement was very important for osteanagenesis. The results of these experiments indicated that BMPC has been good biocompatibility and osteogenesis.

\section{Conclusions}


Here we developed an degradable self-setting BMPC by combining $\mathrm{Ca}\left(\mathrm{H}_{2} \mathrm{PO}_{4}\right)_{2}$ with carboxymethyl chitosan. With the increase of $\mathrm{Ca}\left(\mathrm{H}_{2} \mathrm{PO}_{4}\right)_{2}$ content, the setting time of BMPC prolonged from 8 mins to 25 mins, which was in line with the needs of bone cement implantation. The compressive strength increased at first and then decreased. After setting for $48 \mathrm{~h}$, the maximum compressive strength reached $38.6 \mathrm{MPa}$, which could meet the compressive strength of non load-bearing bone of human. BMPC can be degraded in simulated body fluid. After degrading, it produced magnesium phosphate and HAP, which was conducive to the formation of autologous bone. The experiment of cytotoxicity and laser confocal microscope of BMPC extracts showed that BMPC samples had good biocompatibility. The results showed that the BMPC fabricated in this study was expected to become a bioactive material with potential clinical application value.

\section{Declarations}

\section{Acknowledgements}

The authors thank Professor Hu Ming and Professor Zhang Jie for helping the synthesis of the materials.

Authors' Contributions: Conceptualization, S.L.; methodology, T.Q. and Zhang yunlong; software, A.H.; validation, L.M.; formal analysis, S.L., T.Q. and Y. Z. ; investigation, T.Q.; resources, L.M.; data curation, T.Q.; writing-original draft preparation, S.L.; Writing-review and editing, Y. Z. and A.H.; Visualization, L.M.; supervision, H.Q.; project administration, S,L. and H.Q. All authors have read and agreed to the published version of the manuscript.

Funding: This research is sponsored by National Key Research and Development Program(CN) (2017YFC0907404).

Availability of data and materials: The datasets during and/or analysed during the current study available from the corresponding author on reasonable request.

\section{Ethical Approval and Consent to participate}

Not applicable.

\section{Consent for publication}

The manuscript has been submitted with the consent of all authors for publication.

\section{Competing interests}

The authors declare that they have no relation, condition, or circumstance that constitutes a potential conflict of interest.

\section{Author details}


1.Key Laboratory of Microecology-immune Regulatory Network and Related Diseases, School of Basic Medicine, Jiamusi University, Jiamusi 154007, China; acefire2008@163.com (S.L.); 2.Department of Chemical Engineering \& Material Science, Stevens Institute of Technology, Hoboken, NJ, 07030, USA; tqu3@stevens.edu (T.Q.); 3.Collage of Pharmacy, Jiamusi University, Jiamusi 154007, China; muliting@163.com (L.M.); 4.Collage of Public Health, Jiamusi University, Jiamusi 154007, China; qiuhongbin@jmsu.edu.cn (H.Q.); 5.Department of Basic Medical Science, School of Medicine, Tongji university, Shanghai, China; hisham_alward@yahoo.com (A.H.); 6.College of Material Science \& Engineering, Jiamusi University, Jiamusi 154007, China; jmsdxzhang@126.com (Y.Z.)

\section{References}

1. Springfield D. Autograft reconstructions. Orthop Clin N Am. 1996;27(3):483-92.

2. Chen SH, Lei M, Xie XH, Zheng LZ, Yao D, Wang XL, Li W, Zhao Z, Kong A, Xiao DM. Bioactive PLGA/tricalcium phosphate scaffolds incorporating phytomolecule icaritin developed for calvarial defect repair in rat model. J Orthop Translat. 2020 Jun 7;24:112-120.

3. Yang S, Leong KF, Du Z, Chua CK. The design of scaffolds for use in tissue engineering. Part II.Rapid prototyping techniques.Tissu Eng,2002,8 (1):1-11.

4. Chandrasekaran S, Ramachandran A, Eapen A, George A. Stimulation of periodontal ligament stem cells by dentin matrix protein 1 activates mitogen-activated protein kinase and osteoblast differentiation. J Periodontol. 2012;84(3):198-203.

5. Jia J, Zhou H, Wei J, Jiang X, Hua H, Chen F, Wei S, Shin JW, Liu C. Development of magnesium calcium phosphate biocement for bone regeneration. J R Soc Interface. 2010 Aug;6(49):1171-80. 7(.

6. Sánchez-Enríquez J, Reyes-Gasga J, Obtaining. $\mathrm{Ca}\left(\mathrm{H}_{2} \mathrm{PO}_{4}\right)_{2} \cdot \mathrm{H}_{2} \mathrm{O}$, monocalcium phosphate monohydrate, via monetite from brushite by using sonication. Ultrason Sonochem. 2013 May;20(3):948-54.

7. Zahra S. Carboxymethyl chitosan: Properties and biomedical applications. Int J Biol Macromol. 2018 Dec;120(Pt B):1406-19.

8. Liu F, Li HY, Wang Z, Zhang HN, Wang YZ, Xu H. Carboxymethyl chitosan reduces inflammation and promotes osteogenesis in a rabbit knee replacement model. BMC Musculoskelet Disord. 2020 Nov 24;21(1):775.

9. Konishi T, Honda M, Nagaya M, Nagashima H, Thian ES, Aizawa M. Injectable chelate-setting hydroxyapatite cement prepared by using chitosan solution: Fabrication, material properties, biocompatibility, and osteoconductivity. J Biomater Appl. 2017 May;31(10):1319-27.

10. Gemma M, Maria-Pau G. Novel magnesium phosphate cements with high early strength and antibacterial properties. Acta Biomater. 2011 Apr;7(4):1853-61.

11. Britta K, Anna V, Theresa B, Martha S, Uwe G, Anita I. Bone regeneration capacity of magnesium phosphate cements in a large animal model. Acta Biomater. 2018 Mar;15:69:352-61. 
12. Whitaker A, Jeffery JW. The crystal structure of struvite, $\mathrm{MgNH}_{4} \mathrm{PO}_{4} \cdot 6 \mathrm{H}_{2} \mathrm{O}$. Acta Crystallogr $\mathrm{B}$. 1970;26:1429-40.

13. Grossardt C, Ewald A, Grover LM, Barralet JE, Gbureck U. Passive and active in vitro resorption of calcium and magnesium phosphate cements by osteoclastic cells. Tissue Eng Part A. 2010 Dec;16(12):3687-95.

14. Rita G, Laura M, Francesca R, Piero B. Tuning the properties of magnesium phosphate-based bone cements: Effect of powder to liquid ratio and aqueous solution concentration.[J]. Mater Sci Eng C Mater Biol Appl. 2019 Feb;1:95:248-55.

15. Liu YH, Kumar S, Kwag JH, Ra CS. Magnesium ammonium phosphate forma[1]tion, recovery and its application as valuable resources: a review. J Chem Technol Biotechnol. 2013;88:181-9.

16. Masuda T, Ogino I, Mukai SR. Optimizing the dimensions of magnesium ammonium phosphate to maximize its ammonia uptake ability. Adv Powder Technol. 2013;24:520-4.

17. Wang AJ, Yuan ZL, Jiao Z, Liu LT, Li JM, Liu Z. Hydration process and microstructure of magnesium potassium phosphate cement with nitrate solution. Sci Total Environ. 2020 Feb;10:703:134686.

18. Gong CT, Fang S, Xia KZ, Chen JT, Guo LY, Guo WC. Enhancing the mechanical properties and cytocompatibility of magnesium potassium phosphate cement by incorporating oxygencarboxymethyl chitosan. Regen Biomater. 2020 Dec;3(1):rbaa048. 8(.

19. Varoni EM, Vijayakumar S, Canciani E, Cochis A, De, Nardo L, Lodi G, Rimondini L, Cerruti M. Chitosan-Based Trilayer Scaffold for Multitissue Periodontal Regeneration. J Dent Res. 2018 Mar;97(3):303-11.

20. Uwe K, Elke V, Tobias R, Frank AM, Katharina Z, Uwe G. Low temperature fabrication of magnesium phosphate cement scaffolds by 3D powder printing. J Mater Sci Mater Med. 2010 Nov;21(11):294753.

21. Vojtova L, Michlovska L, Valova K, Zboncak M, Trunec M, Castkova K, Krticka M, Pavlinakova V, Polacek P, Dzurov M, et al. The Effect of the Thermosensitive Biodegradable PLGA-PEG-PLGA Copolymer on the Rheological, Structural and Mechanical Properties of Thixotropic Self-Hardening Tricalcium Phosphate Cement. Int J Mol Sci. 2019 Jan 17;20(2):391.

22. Elaine LD, David BN, Myra HW, Erica NG, Weike T, Neeti S, Lina FC, Donald DM, Kenneth JL The impact of ambient operating room temperature on neonatal and maternal hypothermia and associated morbidities: a randomized controlled trial. Am J Obstet Gynecol. 2016 Apr;214(4):505.e1505.e7.

23. Roizen MF, Sohn YJ, L'Hommedieu CS. Operating room temperature prior to surgical draping: effect on patient temperature in recovery room. Anesth Analg. 1980 Nov;59(11):852-5.

24. Liao JG, Lu SX, Duan XZ, Xie YF, Zhang YX, Li YQ, Zhou AG. Affecting mechanism of chitosan on water resistance of magnesium phosphate cement[J]. Int J Appl Ceram Tec. 2018;15(2):514-21.

25. Li H, Chang J. Fabrication and characterization of bioactive wollastonite/PHBV composite scaffolds. Biomaterials. 2004;25:5473-80. 
26. Miranda RB, Fidel SR, Boller MAA. L929 cell response to root perforation repair cements: an in vitro cytotoxicity assay. Braz Dent J. 2009;20(1):22-6.

27. Shuang W, Chao X, Yu SC, Wu XP, Zhou J, Dai HL. Citric acid enhances the physical properties, cytocompatibility and osteogenesis of magnesium calcium phosphate cement. J Mech Behav Biomed Mater. 2019 Jun;94:42-50.

28. O'Neill R, McCarthy HO, Montufar EB, Ginebra MP, Wilson DI, Lennon A, et al. Critical review: Injectability of calcium phosphate pastes and cements. Acta Biomater. 2017;50:1-19.

29. Li C, Hao W, Wu C, Li W, Tao J, Ai F, Xin H, Wang X. Injectable and bioactive bone cement with moderate setting time and temperature using borosilicate bio-glass-incorporated magnesium phosphate. Biomed Mater. 2020 Jun 16;15(4):045015.

30. Burguera $E F, X u H H$, Weir MD. Injectable and rapid-setting calcium phosphate bone cement with dicalcium phosphate dihydrate. J Biomed Mater Res B Appl Biomater. 2006 Apr;77(1):126-34.

31. Liu C, Gai W, Pan S, Liu Z. The exothermal behavior in the hydration process of calcium phosphate cement. Biomaterials. 2003;24(18):2995-3003.

32. Ahmed K, Zaidi SF, Mati-Ur-Rehman, Rehman R, Kondo T. Hyperthermia and protein homeostasis: Cytoprotection and cell death. J Therm Biol. 2020;91:102615.

33. Roseti L, Parisi V, Petretta M, Cavallo C, Desando G, Bartolotti I, et al. Scaffolds for Bone Tissue Engineering: State of the art and new perspectives. Mater Sci Eng C Mater Biol Appl. 2017;78:124662.

34. Rather HA, Jhala D, Vasita R. Dual functional approaches for osteogenesis coupled angiogenesis in bone tissue engineering. Mater Sci Eng C Mater Biol Appl. 2019;103:109761.

35. Sharma P, Pandey PM. Corrosion rate modelling of biodegradable porous iron scaffold considering the effect of porosity and pore morphology. Mater Sci Eng C Mater Biol Appl. 2019;103:109776.

36. Staiger MP, Pietak AM, Huadmai J, Dias G. Magnesium and its alloys as orthopedic biomaterials: a review. Biomaterials. 2006;27(9):1728-34.

\section{Tables}


Table 1

Relative growth rate (RGR)

and cytotoxicity grade

standard.

\begin{tabular}{|ll|}
\hline RGR(\%) & Toxicity Grade \\
\hline$\geq 100$ & 0 Grade \\
\hline $75 \sim 99$ & 1 Grade \\
\hline $50 \sim 74$ & 2 Grade \\
$25 \sim 49$ & 3 Grade \\
\hline $1 \sim 24$ & 4 Grade \\
0 & 5 Grade \\
\hline
\end{tabular}

Table 2. The hydration products of BMPC after setting for $48 \mathrm{~h}$ and soaking for $28 \mathrm{~d}$ tested by XRD.

\begin{tabular}{|c|c|c|c|c|}
\hline & BMPCO & BMPC20 & BMPC40 & BMPC60 \\
\hline Setting for $48 \mathrm{~h}$ & $\mathrm{Qu}$ & 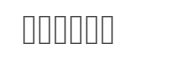 & प्या० & प्स० \\
\hline Soaking for $28 d$ & प्स & प्यास्स & प्स० & 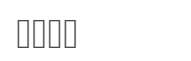 \\
\hline
\end{tabular}

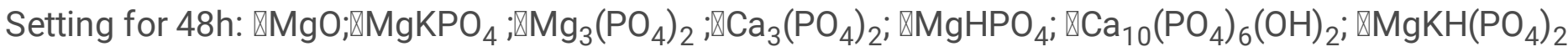

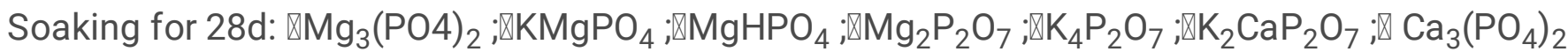
$; \mathbb{Z C a}{ }_{10}\left(\mathrm{PO}_{4}\right)_{6}(\mathrm{OH})_{2}$

Table 3

The relative growth rate( $R G B)$ and toxicity grade(TG) of BMPC samples.

\begin{tabular}{|lllllll|}
\hline Group & 1d & & 3d & & 5d & \\
\cline { 2 - 7 } & RGB(\%) & TG & RGB(\%) & TG & RGB(\%) & TG \\
\hline BMPC0 & 81.75 & 1 & 75.68 & 1 & 76.08 & 1 \\
\hline BMPC20 & 89.68 & 1 & 84.93 & 1 & 83.95 & 1 \\
\hline BMPC40 & 103.97 & 0 & 108.90 & 0 & 103.12 & 0 \\
\hline BMPC60 & 107.14 & 0 & 113.01 & 0 & 107.58 & 0 \\
\hline
\end{tabular}

Figures 


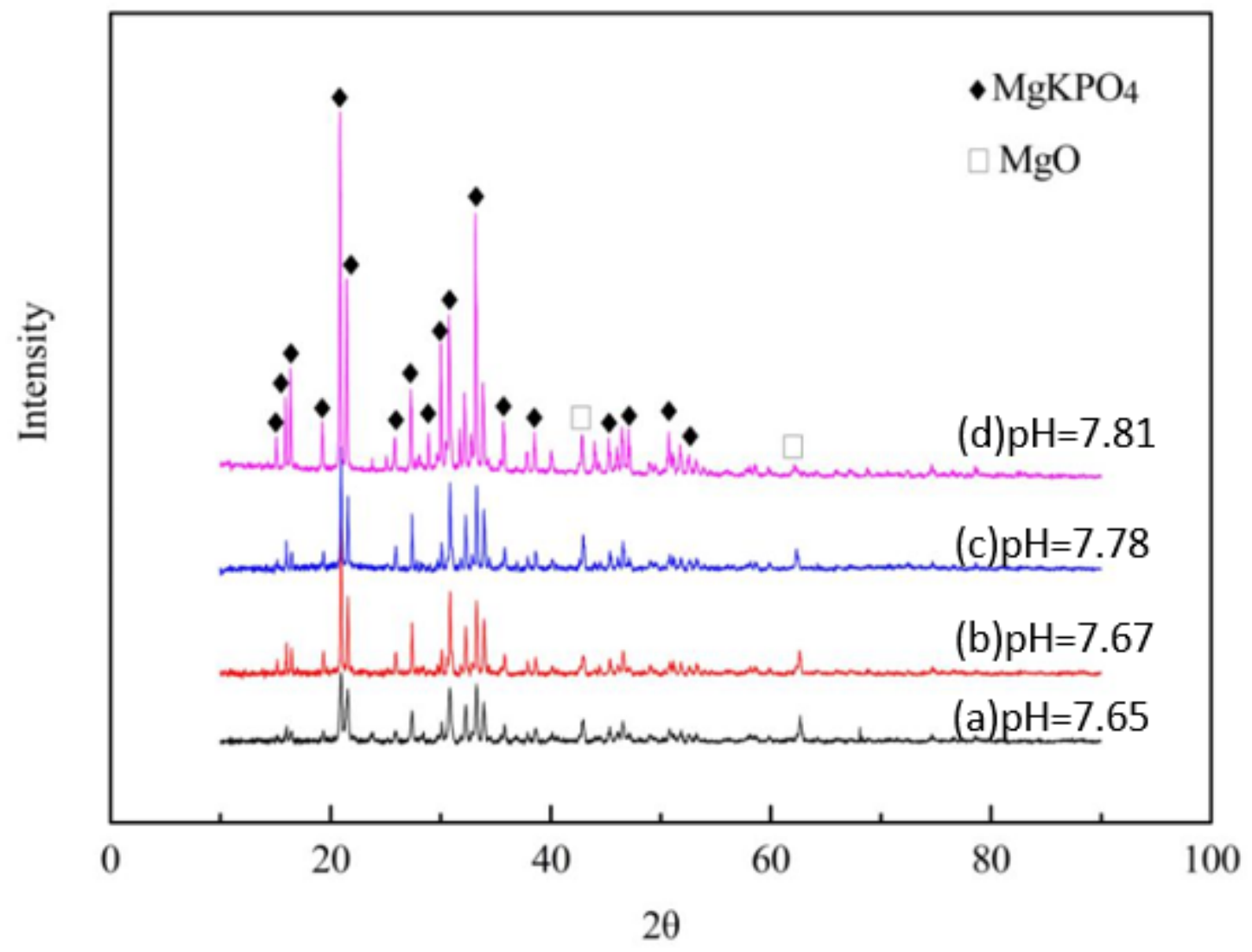

Figure 1

The hydration products and pH of MPC specimens. (a) 1:2; (b) 1:3; (c) 1:4; (d) 1:5. 

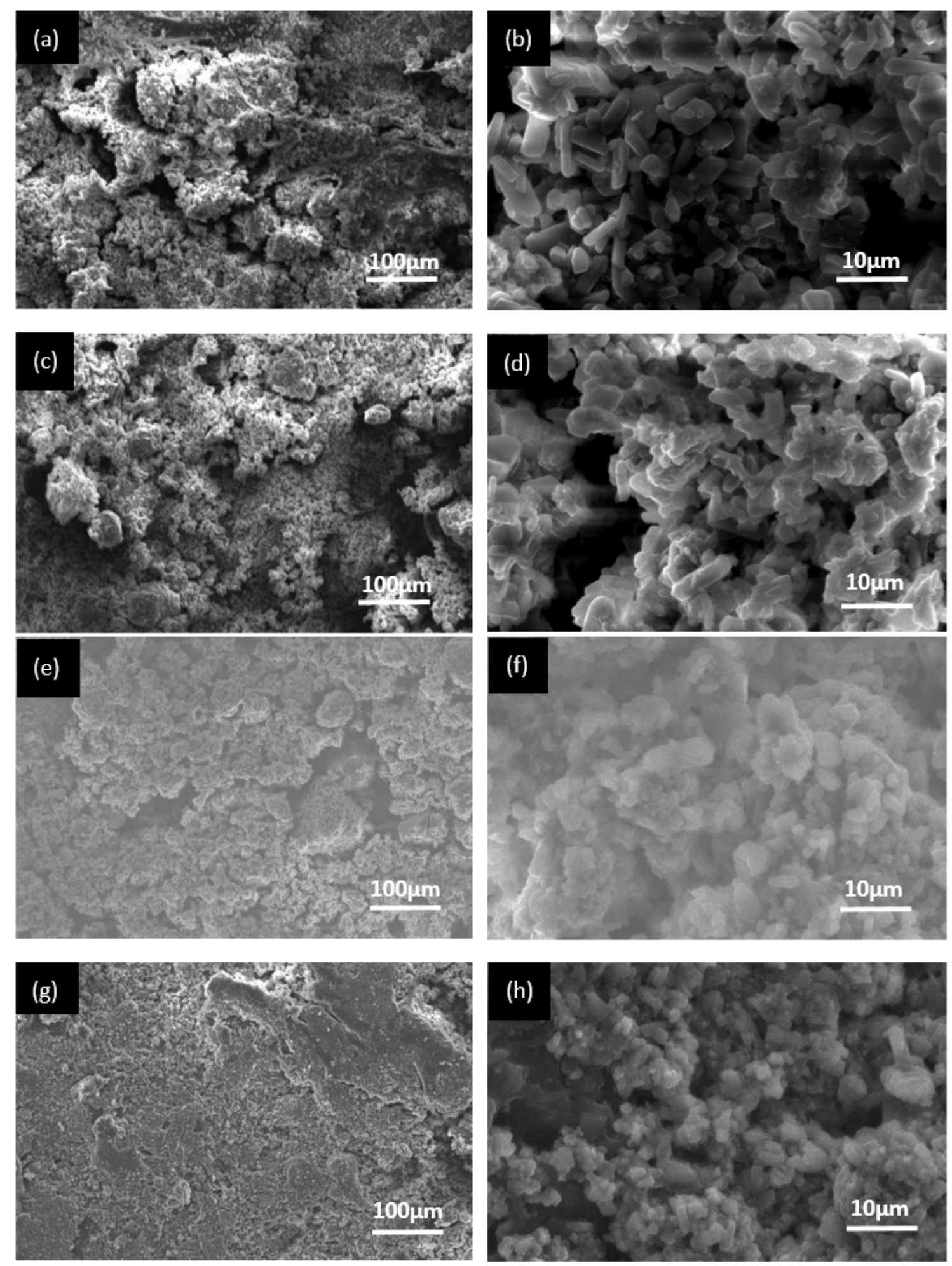

Figure 2

SEM images of BMPC samples. (a,b)BMPC0 (c,d) BMPC20 (e,f) BMPC40 (g,h) BMPC60. 


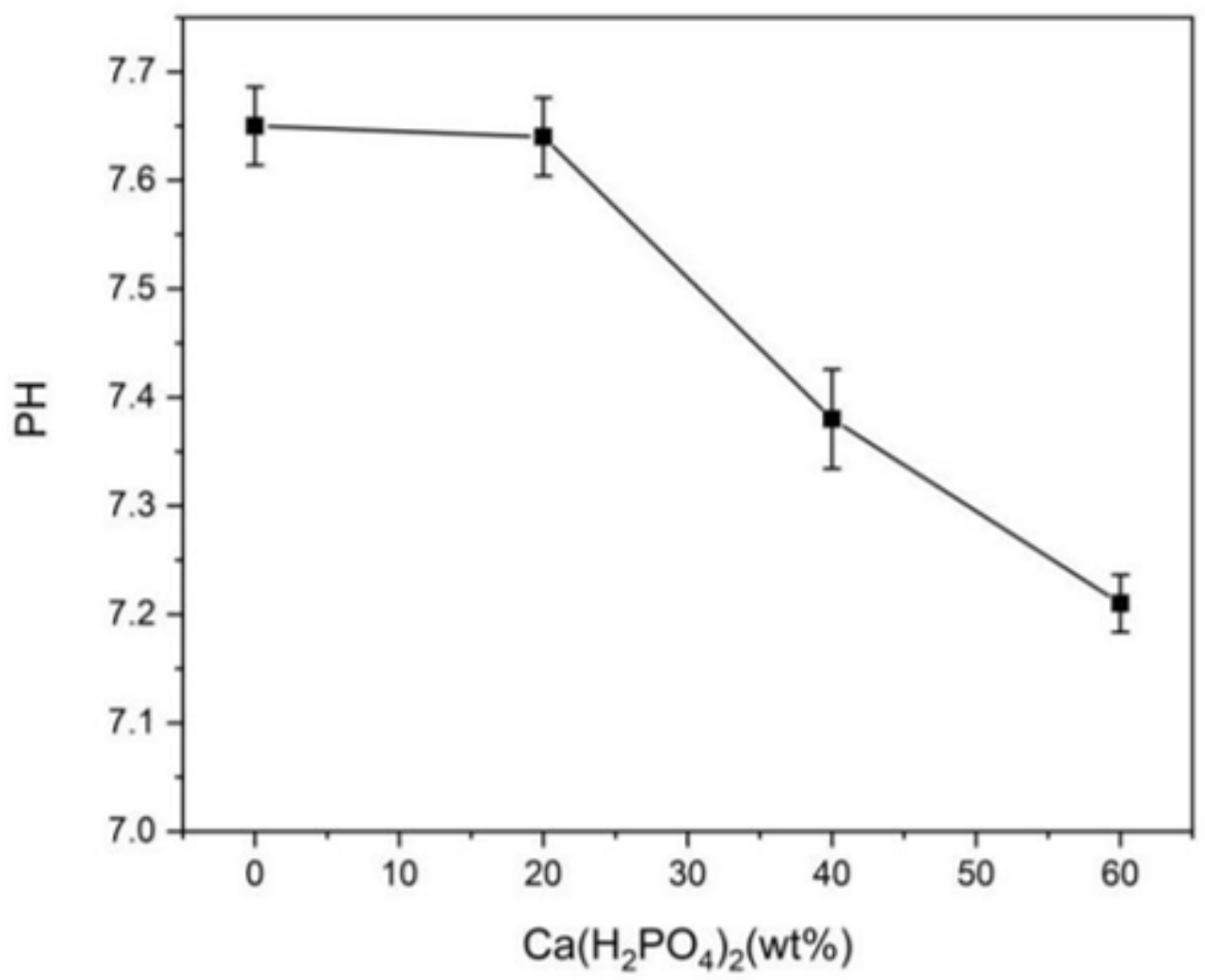

Figure 3

pH of BMPC extracts with $\mathrm{Ca}\left(\mathrm{H}_{2} \mathrm{PO}_{4}\right)_{2}$. 


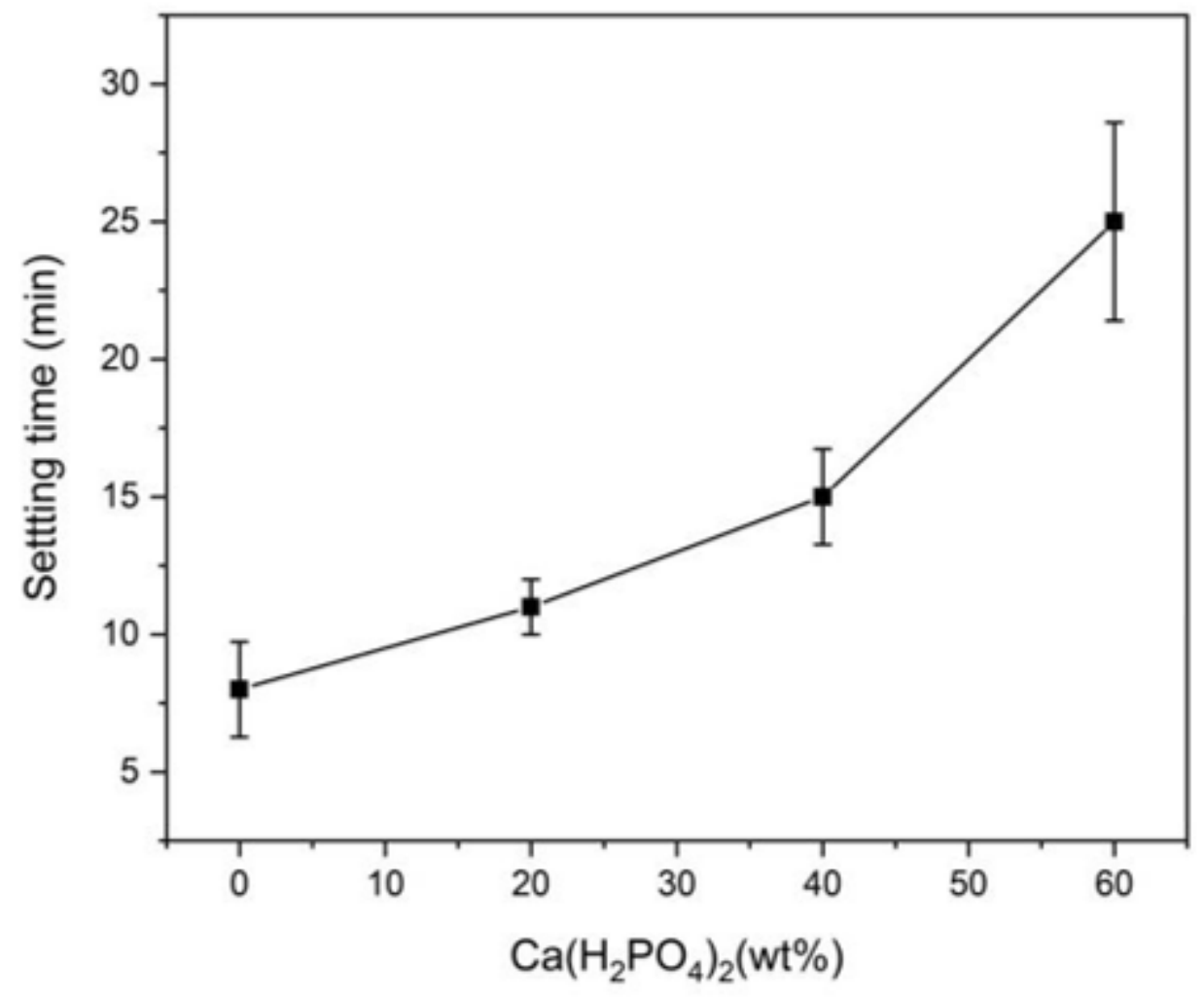

Figure 4

The setting time of BMPC specimens with $\mathrm{Ca}\left(\mathrm{H}_{2} \mathrm{PO}_{4}\right)_{2}$.

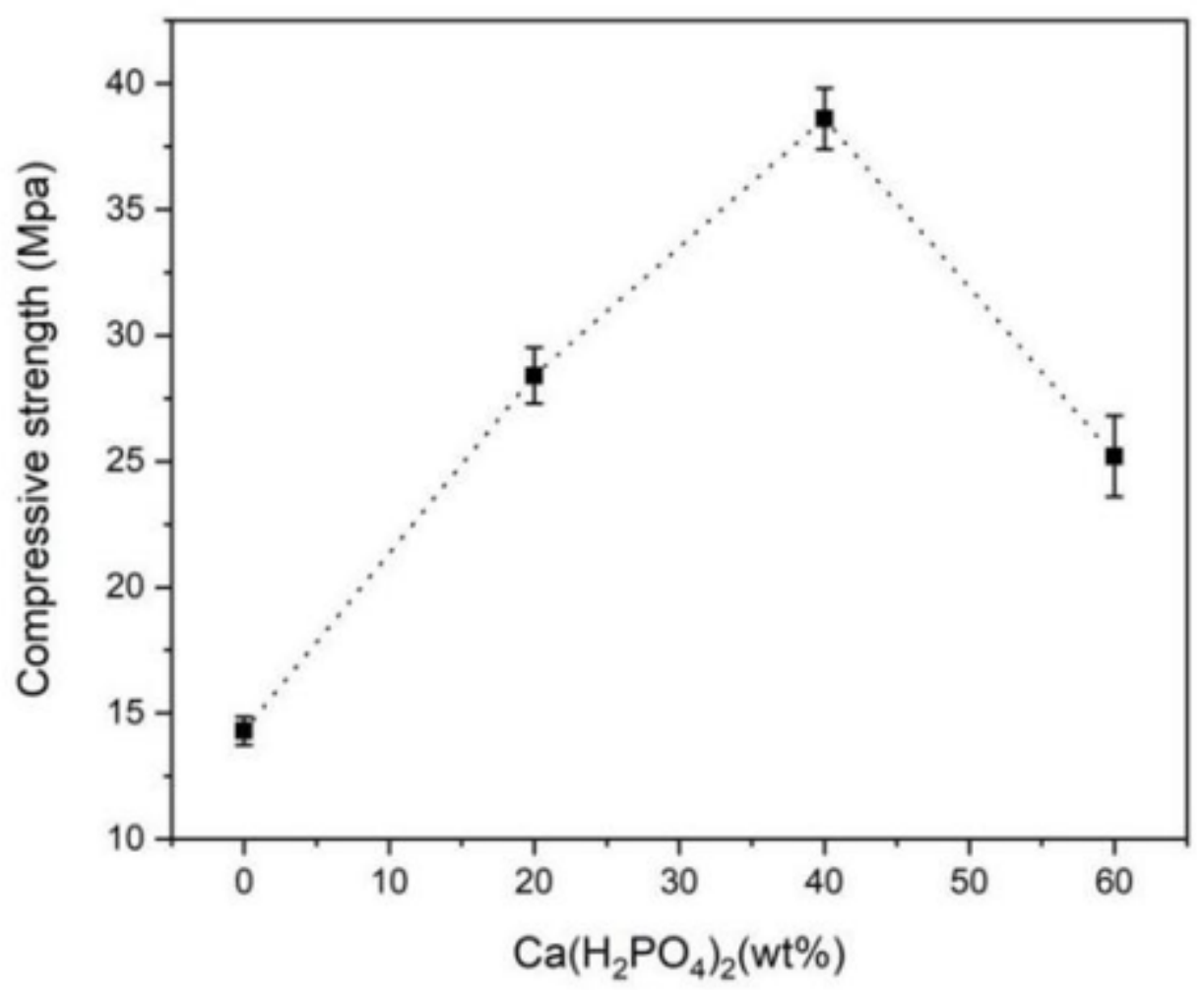

Figure 5 
The compressive strength of BMPC specimens with $\mathrm{Ca}\left(\mathrm{H}_{2} \mathrm{PO}_{4}\right)_{2}$.

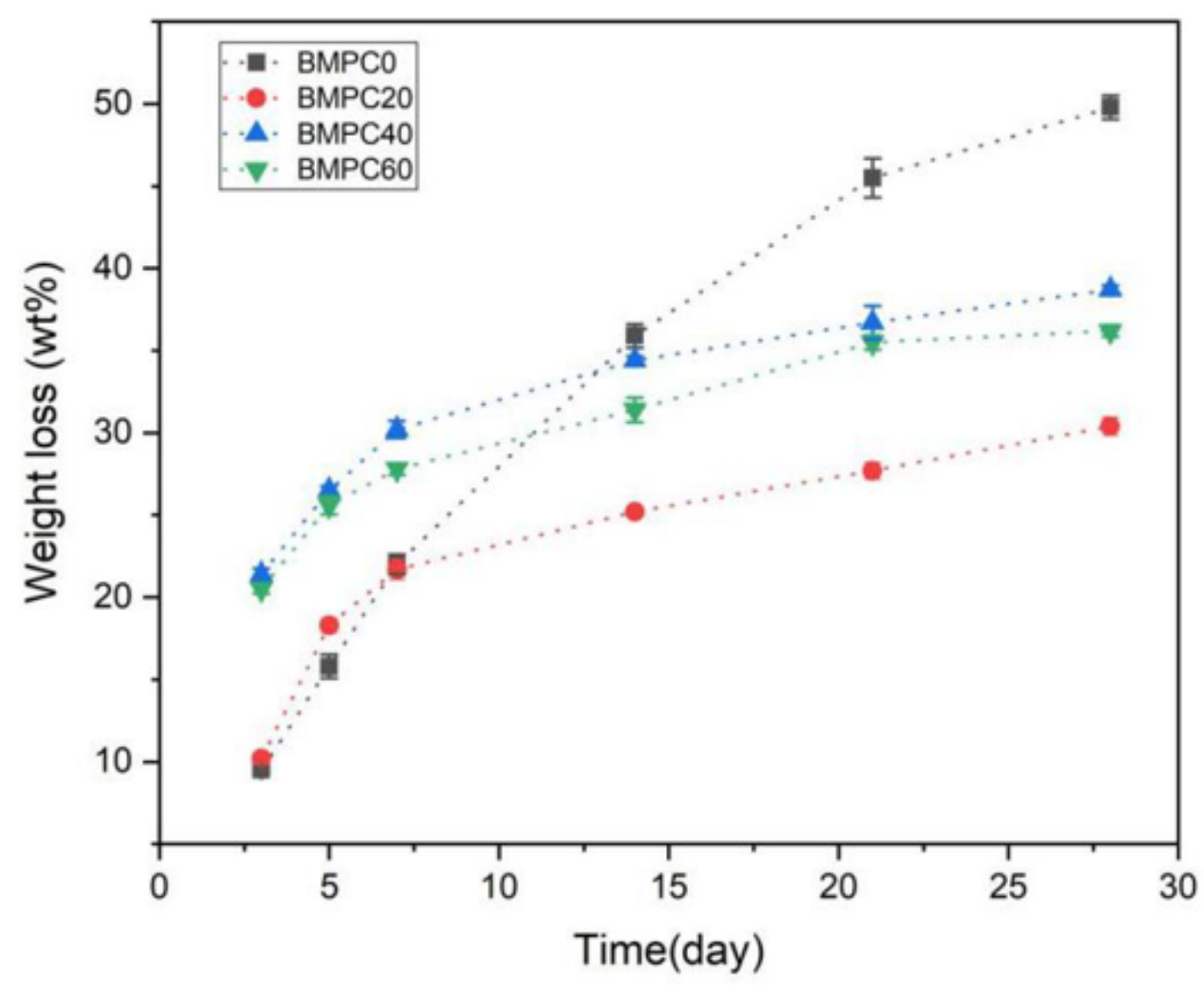

Figure 6

The degradation rate of BMPC samples with $\mathrm{Ca}\left(\mathrm{H}_{2} \mathrm{PO}_{4}\right)_{2}$. 


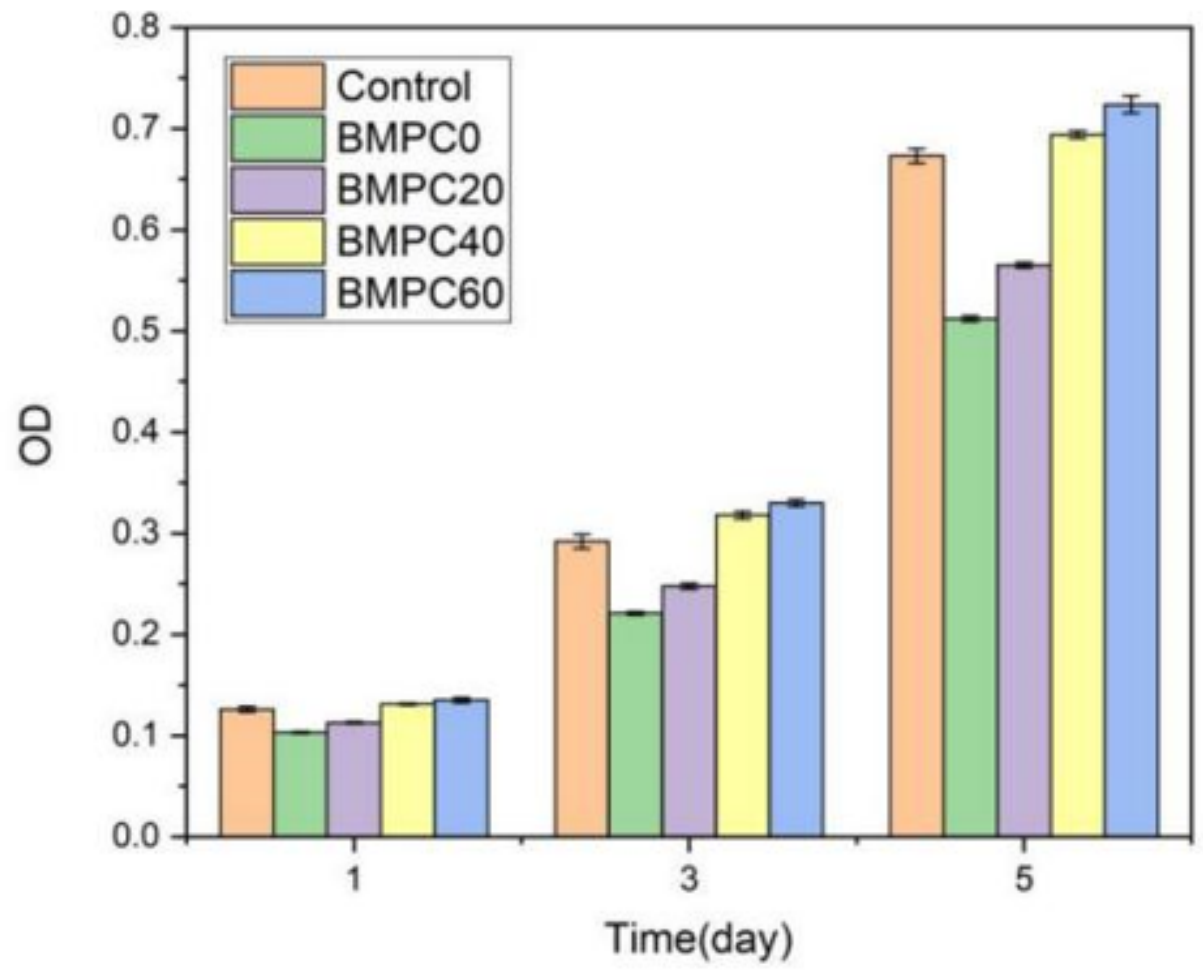

Figure 7

The cytotoxicity of BMPC samples. 

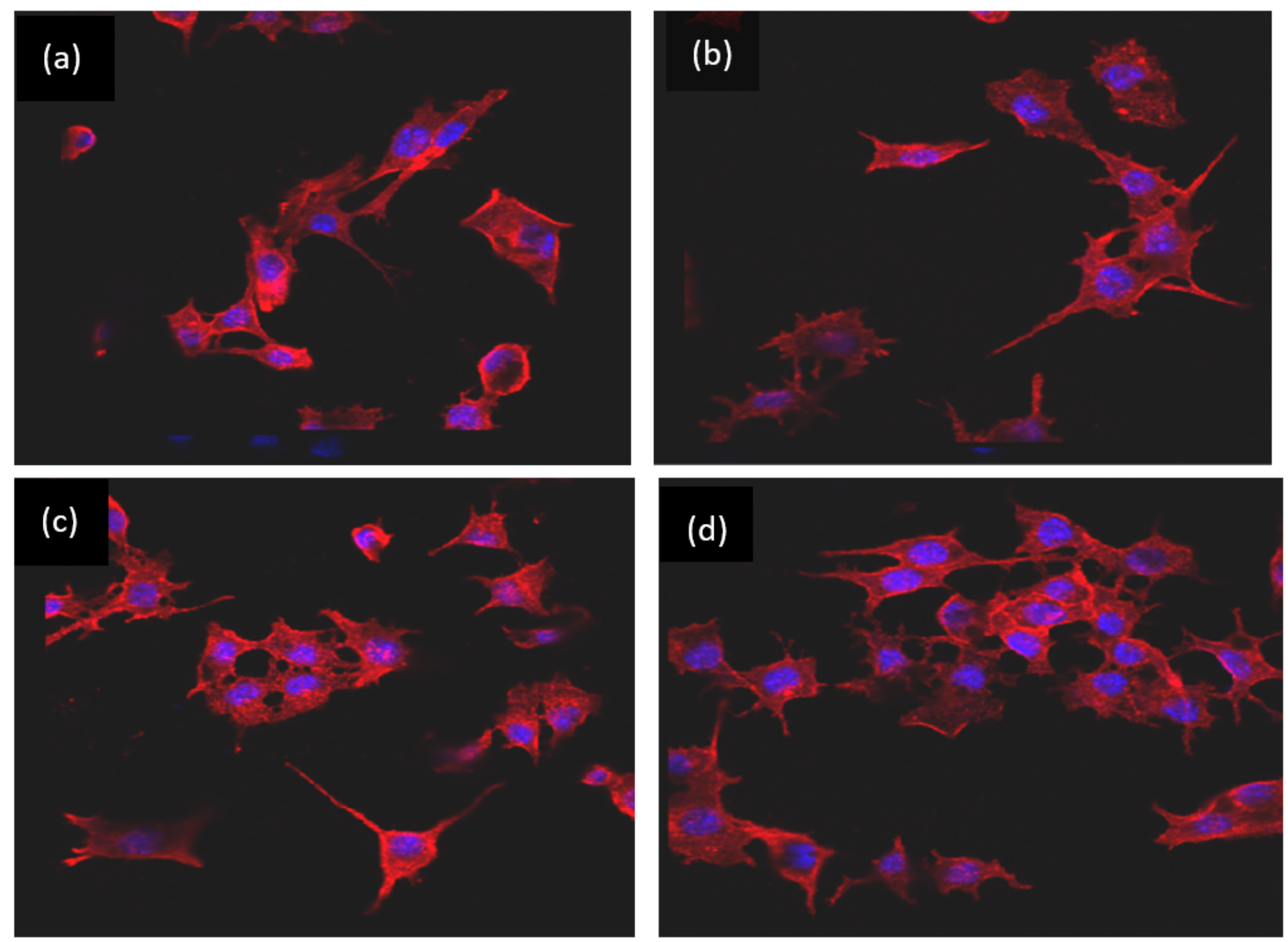

\section{Figure 8}

The images of laser confocal microscopy experiment of BMPC samples. (a) BMPC0; (b) BMPC2; (c) BMPC40; (d) BMPC60. 